DOI 10.37882/2223-2982.2021.04-2.41

\title{
ЭВФЕМИСТИЧЕСКИЕ МОТИВЫ \\ В РАССКАЗЕ М.Л. КАШНИЦ «ПРИЗРАКИ»
}

\section{EUPHEMISTIC MOTIFS IN THE SHORT STORY "GHOSTS" BY M.L. KASHNITS}

O. Iatsevich

V. Iudashkina

A. Sokolov

Summary: In this article, the authors analyze the euphemistic motifs in the short story "Ghosts" by M.L. Kashnits through the interpretation of the concept "Gespenster". As a methodological basis, the authors rely on the ontogenetic analysis of the key components of the above-mentioned word form. In this paper, it is concluded that the etymological analysis of the name of the story is able to reveal the main idea, veiled by the author.

Keywords: euphemistic motifs, short story, narrative, word form, etymology, ontogenetic analysis, "Gespenster".
Яцевич Ольга Евгеньевна

К.ф.н., доцент, Тюменский индустриальный университет marusafronova@gmail.com

Юдашкина Валентина Владимировна старший преподаватель, Тюменский индустриальный университет

brentano@yandex.ru

Соколов Александр Николаевич

К.филол.н., Тюменский государственный институт культуры

alex_zander77@mail.ru

Аннотация: В данной статье авторы анализируют эвфемистические мотивы в коротком рассказе М.Л. Кашниц «Призраки» через интерпретацию понятия «Gespenster». В качестве методологической основы авторы опираются на онтогенетический анализ ключевых составляющих вышеназванной словоформы. В данной работе делается вывод 0 том, что этимологический анализ названия рассказа способен раскрыть основную идею, завуалированную автором.

Ключевые слова: эвфемистические мотивы, короткий рассказ, повествование, словоформа, этимология, онтогенетический анализ, «Gespenster».

после войны, и, конечно, книги стоили больше, чем газеты, в которых публиковались короткие истории. Было выгоднее печатать в каждом номере новый рассказ, чем части длинного романа, поскольку в таком случае периодическое издание приходилось бы покупать на постоянной основе.

В данной статье авторы проанализировали короткую историю «Gespenster» [6], вышедшую из-под пера немецкой писательницы Мари Луизы Кашниц (1901-1974). Эта историявходилав разноевремяв рядантологий:European Tales of Terror/Европейские истории о терроре, Окна напротив и Таинственный святой, Gespenstergeschichten/ Истории о приведениях [5]. Лирика и проза М.Л. Кашниц эвфемистична, в чём заключается сила и талант автора. Писательница умело играет языком, зная точно, какие лингвистические средства выбрать, чтобы читающий почувствовал себя тронутым и вовлеченным в действие. В произведениях мастера слова можно распознать множество повторяющихся универсальных мотивов: любовь, одиночество, антиномичные сюжеты, где соседствуют жизнь и смерть. В слова облекается всё то, к чему нельзя прикоснуться, мысли главных героев словно кричат со станиц, становясь вовсе не внутренними монологами, а чем-то более осязаемым [8].

В рассказах Кашниц М.Л. часто можно наблюдать саму эссеистку, любившую так путешествовать со своим 
супругом археологом, открывая новые местности, архитектуру. Посещая культурные объекты, супружеская чета знакомилась с новыми, необычными людьми. Произведение, известное в русском переводе под названием «Призраки» знакомит аудиторию с ранними поездками Кашниц-Вайнберг.

Действие рассказа разыгрывается в Лондоне, богатом своим историческим прошлым и наполненном всякого рода мистикой, где реальность и мистицизм сплелись воедино. Странным кажется выбор молодой пары, слабо владеющей английским языком и отправившейся в театр Old Vic для просмотра пьесы У. Шекспира. Стены театра помнят множество ролей, актеров, великих посетителей, их мысли и судьбы, начиная с середины XIX века. Первоначально это известное заведение именовалось Кобургским театром, но после визита принцессы Виктории, он был переименован и существует уже более полуторостолетий под известным по сей день именем.

Главные действующие лица: молодая супружеская пара (Антон и его безымянная жена из Австрии) и брат с сестрой-англичане (с французскими именами Вивьен и Лурье), которые знакомятся друг с другом во время представления и отправляются к странной парочке домой. Жилище англичан кажется похожим на другие соседские дома, и только хранитель дома - каменная кошка, присела в смирном ожидании своих хозяев. Всё кажется молодым супругам в новых знакомых необычным: цвет волос, голоса, одежда, которая не вписывается в формат посещения Old Vic.

Выражение лиц брата и сестры описывается как грустное и холодное (trauriges Gesicht; eine feine, helle Gesichtsfarbe; sah unglücklich aus) а движения как плавные и медленные, словно во сне (merkwürdig langsam; antwortete langsam, als ob er sich nicht erinnern könnte, fast wie im Schlaf). Казалось, что молодые англичане не устают и не испытывают чувства голода. Танец, в котором Вивьен кружила Антона, оставил без сил не только его самого, но и наблюдавшую за сим действом его спутницу жизни. После общения с англичанами, герои испытывают чувство усталости и тревожности (Er war zuerst still und sah müde. Plötzlich wurde ich sehr müde. Aber wir waren beide sehr müde, sah müde aus). Автор использует в рассказе глаголы состояния (sein используется более десяти раз), чтобы показать статичность истории, однообразие жизни главных героев, их вынужденное бездействие. Глаголы восприятия sehen, schauen выполняют смыслообразующую функцию, являются способом установления контакта между героями [2].

Почему же автор напрямую не называет вещи своими именами? Откуда этот страх? Возможно, ответ находится в онтогенетическом анализе самого понятия «Gespenster», которое другие исследователи произведений М.Л.
Кашниц оставили без должного внимания.

Немаловажно, что сама словоформа «Gespenster»/ «призраки» ни разу не употребляется в повествовании, хотя вынесена в заглавие. Возможно, такая тактика была выбрана писательницей по эвфемистической причине, когда явления в силу ряда причин не называются напрямую, используются иносказания или другие заменяющие описатели. Нарратив наполнен описаниями, вселяющими в австрийских путешественников недоумение и страх: неподходящий стиль одежды Вивьен и Лурье, странный дом с отсутствующим электричеством, неработающим телефоном и спёртым неживым запахом. Неслучайно на пяти страницах автором 6 раз употребляется слово merkwürdig/странный, необычный, удивительный, диковинный (ein merkwürdiges Gefühl von Freude; Sie gingen merkwürdig langsam; merkwürdiges Haus; ein bisschen merkwürdig; Wir fanden es nur merkwürdig), что подталкивает авторов статьи к проведению этимологического анализа заголовка.

«Gespenst»/ «призрак» в немецком языке функционирует в форме существительного среднего рода в значениях «Spukgestalt, Geist» / «призрачный облик», «дух» и восходит к древневерхненемецкому «gispensti»/ «заманивание, соблазнение, внушение», которое существует в немецком языке с 9 века; в средневерхненемецком зафиксировано как «gespanst», «gespenst» в форме женского рода; древнесаксонское «gispensti» (ср.род); средненижненемецкий «gespens(t)» сопоставлен с древневерхненемецким «spanst» и средневерхненемецким «spenst» / «соблазн, обольщение», которое связано в свою очередь с южно-немецким абстрактным глаголом «spannen»/ «притягивать, обольщать», в новом верхненемецком потерявшем своё существование сильном глаголе. Таким образом, призрак на самом деле это чтото или кто-то, кто «was jmdn. wegzieht, weglockt»/ «кто кого-то уводит, заманивает».

Слово «gast» близко по значению «Gespenst», пришло из древнеанглийского и означает «добрый или злой дух, ангел, демон, человек». В библейских текстах используется «gaistaz», пришедшее из западногерманского языка со значением «душа, дух, жизнь» (древнесаксонский «gest», древнефризский «jest», средненидерландский «gheest», голландский - «geest», немецкий «Geist» «spirit, ghost»). Корень gheis-, использованный при образовании данных слов, обозначает понятия, выражающие удивление, волнение, страх, изумление [4].

Английский вариант данной истории известен под названием «Ghost». Ghost - призрак, слово из западногерманского, обозначающее «сверхъестественное существо». В христианской письменности на древнеанглийском языке оно используется для перевода латинского spiritus (в значении «бестелесного духа мертвеца», осо- 
бенно воображаемого как блуждающий среди живых или преследующий их, засвидетельствован с конца 14 в. и возвращает слово к его вероятному доисторическому смыслу.

Heinrich Tischner полагает, что призраки это внутренние образы, которые мы порождаем нашим собственным воображением. С их названием связано иностранное слово «призрак»/ «Phantom» (в старофранцузском «fantosme» от греческого «phántasma» / «явление, мозг, представление» [7]. Основное занятие призраков - являться кому-то в качестве видений (нем. Spuk), происходит от средне-германского «gespüс»/ ужасное событие со злыми последствиями.

Молодые брат и сестра, будучи мёртвыми, не хотят покидать этот мир и пытаются сосуществовать с живыми людьми, пытаясь с былым азартом, какой был присущ им раньше и с каким они гоняли на своём модном автомобиле, косвенно наводить ужас на других людей, вселяя в них чувство безумия и страха [1].

Наверное поэтому, молодые супруги, осознав весь ужас ситуации, подумали, что приключения, случившиеся с ними днём раньше было ничем иным, как сном, видением, дымкой. Как могла Вивьен кипятить чайник, в доме, где нет электричества, как играла музыка из радиоприёмника, и почему так молодая де- вушка манила Антона к себе. Эти и другие вопросы возникали в голове у рассказчика и позже ее мужа. И лишь найденный портсигар, накануне оставленным на столе, говорил о том, что всё случившееся вовсе не видение, а быль.

Можно сказать, что на этом странном визите в дом погибших Вивьен и Лурье, мистичность истории не закончилась, потому что австрийцы следующим пунктом своей программы наметили посещение галереи Тейт, в которой в качестве экспонатов находятся известные произведения («Благовещение» Д.Г. Росетти и «Сатана»У. Блейка), изображающие два параллельных мира. Антиномийные чувства, красной нитью протягивающиеся сквозь повествование, совмещают в себе реальность и вымысел, соседство рассудка и безрассудности, хаоса и порядка. Реальность и вымысел, таким образом, встречаются друг с другом в каком-то противоречии, абстрактное приобретает черты конкретного, что так влечет к себе читательскую аудиторию, пытающуюся сквозь слова понять потайной смысл жизни.

Таким образом, с помощью языковых приёмов создаётся угнетающее настроение; раскрывается семантика названия Gespenster через описание, языковые приёмы, сравнения, эмоциональные интенсификаторы; используется нейтральная лексика, создающая тревожное предчувствие, не прибегая к прямой номинации.

\section{ЛИТЕРАТУРА}

1. Куклина Т.В. Внутренняя речь как «поток сознания» в рассказе М.Л. Кашниц «Gespenster» В сборнике: Фундаментальные проблемы лингводидактики в контексте современных требований к иноязычному образованию. Материалы всероссийской заочной научно-практической конференции. Отв. ред. О.В. Кравец. 2020. С. 31-34.

2. Лапчинская Т.Н. Смыслообразующая функция семантических типов полнозначных глаголов в тексте немецкого короткого рассказа // Культура и Цивилизация. 2015. № 6. С. 261-279.

3. Халиуллина А.Р. Стилистические особенности перевода в произведении М.Л. Кашниц «Призраки» // Академическая публицистика. 2021. № 1. С. 200-202.

4. Digitales Worterbuch der deutschen Sprache URL: https://www.dwds.de/wb/Gespenst (дата обращения: 15.03.21).

5. Gespenstergeschichten. Herausgegeben von Dietrich Weber. Anaconda Verlag, GmbH, Köln, 2017. S.9-23.

6. Kaschnitz M.L. Gespenster URL: https://talesofmytery.blogspot.com/2013/09/marie-luise-kaschnitz-gespenster.html (дата 0бращения: 10.01.2021).

7. Tischner H. Gespensterspuck. Sprachecke in den Echo-Zeitungen. URL: https://www.heinrich-tischner.de/22-sp/9sp-ecke/artikel/201/2015/15-11-03.htm (дата обращения: 11.03.21).

8. Ziese J. Die subjektive Instanz in den Erzählwerken von Marie Luise Kaschnitz, Magisterarbeit, 2005.

(с Яцевич Ольга Евгеньевна (marusafronova@gmail.com ), Юдашкина Валентина Владимировна (brentano@yandex.ru), Соколов Александр Николаевич (alex_zander77@mail.ru). 